\title{
ラセン器の直流電位と $\mathrm{CM}$ の分布
}

\author{
鶴兒大学歯学部生理学教室 \\ 田中康夫*, 浅沼 厙, 柳沢慧二, 勝木保次** \\ （*京咐医大・耳， **東京医歯大）
}

\section{緒言 \\ モルモットなどの動物に括いて経正円㥶ゔセン器刺} 入時に,「コルチ器負電位」と呼ばれる負性の直流電位 と螖牛マイクロホン電位 ( $\mathrm{CM}$ ) が記録されることは Békésy ${ }^{1)}$ や田崎 ${ }^{10\rangle}$ の報告以来よく知られている。 蝸牛中央階汇約 $80 \mathrm{mV}$ の正電位 (E P)があり, ラセ ン器と中央階の境介で CMの位相が 180 度転換するこ とから, ラセン器表面を被う網状膜江 CMの発生源が あると想定され, variable resistance microphone theory が成立っている。この説では，CM は網状膜 部の可变抵抗が音刺激汒より増滅するために起る電圧 降下の変動であると説明されている。

ラセン器刺入時得られる電位のうち, いわゆる 「コルチ器負電位」は発見当初 ${ }^{11}$, ラセン器の細胞要素 飞由来するすのと考光られたが，此較的太い先端（経 $25 \mu$ 以上)の電極でも記録されるので細胞外のものと

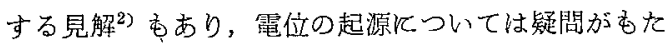
れてきた。 Lawrence ${ }^{6)}$ は実験結果をラセン器の形態 学的計測徝から推測して、「コルチ器負電位」妨ラセン 器の細胞を含む全体のものとし, また蓋膜飞は不安定 な零近辺の電位があることから C M の発生源を蓋膜に 求めている。一方, 水生動物の側線器飞扔いて感覚毛

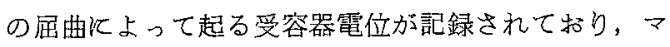
イクロホン電位はそれらの細胞外集合電位であること がわかりつつある。以前よりマイクロホン電位慣な る随伴現象ではないかという意見がしばしばあった が, 水生動物の場合, 求心神経終末の興䔃をひき起す 前段階としての生理学的な電気現象である。哺乳類で は，いまだ毛細胞内の電位は十分明らかにはされてい ない。

このよろに，CMの成因ひいてはラセン器に括ける 変換機序を理解する上飞,な怙未解決の問題が多く残 されている。本実験ではラセシ器刺入時飞得られる電 位について, 電位分布を再検討し, マーキング法 ${ }^{11) を ~}$ 用いて直流負電位の細胞同定を行い，さら飞蓋膜就よ
び蓋膜下腔の電位についても追求した。それらの結果 について述べる。

\section{実 験 方 法}

実験動物《は 200 450g のモルモットを用いた。 ペントバルビダールソーダ $30 \mathrm{mg} / \mathrm{kg}$ の腹腔内注射 よる麻酔下, 気管切開を施しポリエチレンチューブを 気管に括入した。動物の頭部を Hess 型改良固定器飞 保持した。ガラミントリエチオダイドとより筋弛緩を 行い, 気管断端のポリエチレンチューブを人工呼吸器 (成茂，AR-2）飞接続した。下顎骨内縁から耳後部 飞向って切開を括き下顎骨角括よび茎状突起を骨膜下 飞剥離除去し; 中耳骨胞を下面より後部的わって大 きく開放し，蛤牛を露呈した。正円空刺入時の照明に は特殊なガラス製のライトガイドを試用した。面径 $1 \mathrm{~mm}$, 長さ $35 \mathrm{~mm}$ のガラス照明素子(オリンパス光 学特製) の幹部を開放した中耳骨胞縁飞歯科用セメン 卜で固定し，先端を螖牛骨壁飞あてグラスファイバー 照明器（成茂, MEI-12) からの光源を蝸牛内に導い た。この照明方法により, 視野が従来よりもはるかに 明るくなり顕微鏡倍率40倍またはそれ以上で正円葖刺 人を行うことができた。

記録打よび細胞マーキング用の電極には先端径 $1 \mu$ 以下のガラス毛細管に色素を充填し, 電極抵抗 $20 \sim$ $100 \mathrm{M} \Omega$ のむのを用いた。中央階灌流兼用の電極沫 先端径 2 10 $\mu$ のガラス管を作製使用した。不関電極 飞注銀板を用い，それを頝部の筋肉飞沏いた。直流電 位は電極より前置堌幅器 (日本光電, $\mathrm{Mz}-4$ ) 経てぺ ン㫪き記録器 (東要電波, EPR-3T) 飞導いた。 $\mathrm{CM}$ は前置増幅器 $\mathrm{Mz}-4$ よりブラウン管オッシロスコープ (Taktronix 565) 上飞モニター乙平均加算機（日本光 電, ATAC-201) 飞記憶させた後, X-Yレコーダ(横 河䉓機 3077)で記録した。音刺激は $200 \sim 4000 \mathrm{~Hz}$ の 純省のトーンバーストを用いた。刺激音圧には $\mathrm{CM}$ 入力対し淔線関係を保つ筑間内の最大音生を動物ご 


\section{とに選んだ。}

細胞マーキング用の色素にばナイアガラスカイブル 一 $6 \mathrm{~B}$ を用い, $4 \%$ 溶液を電極飞充填した。電位の記 録後ただちに電極記録系より通電系に切り換え, $5 \times 10^{-7} \mathrm{~A}$ の㓌極電流を 1 秒ごとに 500 ミリ秒の短形 波として 10 15 分間通じ色紊を泳動さ吼た。染色さ れた細胞の检索は, 断頭後摘出した螖牛を $5 \%$ グルタ ールアルデヒド溶液で固定し作製した surface preparation上で行った。細胞外の部位同定は色素が拡散し てしまい困難であるので，蓋膜部には神経線維の走行 や分岐をみるため行われているコバルト沈着法》を試 みた。本来これは Co イオンを電気泳動的に流出さ䛧 硫化火よる黒色沈着物を検出する方法であるが，細胞 外飞対してはイオン数が十分でなく本业験では中央階 灌流によった。排出口を螖牛頂に作り，力コディレー 卜緩衝液加 $200 \mathrm{mM}$ 塩化コバルト溶液約 $1 \mathrm{~mm}^{3}$ を正 门密刺人により中央階に注入した。摘出した螖牛を $2 \%$ 硫化アンモン溶液に浸し発色させた後，5\%グル タールアルデヒド溶液で $12 \sim 24$ 時間固定した。 $2.5 \%$ グルタールアルデヒド溶液で生体固定を行った動物の 場合西螖牛摘出後，同様飞発色さ尔再固定した。組織 学的な检索は surface preparation 䄮よび radial sectionの両標本により行った。

\section{実 験 成 績}

正円空を経て基底膜をできる限り垂直飞刺入し中央 階淌って電極を進める際の直流記録とついて, 電極 先端が正円荌膜に接した時の直流レベルを零電位とす ると，鼓室階では通常零電位，時に正门䓡膜の王迫に

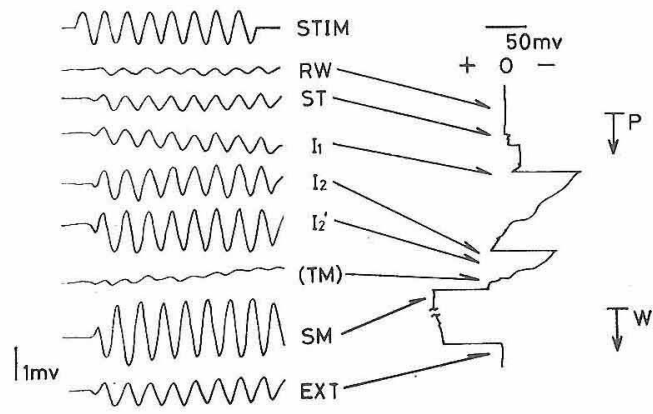

図 1 経正门空ラセン器刺入時の CM 扎よび DC 記録。図左は $3,000 \mathrm{~Hz}$ の純音刺激に対する $\mathrm{CM}$ ，図右は DC 記録。 RW：正円空，ST：鼓 室階，I：細胞内， TM：蓋膜， SM：中央階, Ext：細胞外。P は電極制入聞始，W は抜去開 始。
より数 $\mathrm{mV}$ 正または負の電位が示される。電極先端が 基底膜を貫通すると: 2 3 回大さい負電位が観察され た後, 中央階の正電位 $\mathrm{EP}$ が得られた（図1, 右)。CM はそれらの負電位の部位で，鼓室階のものと較べ同様 な大きさの場合と増大する場合があった。CMの位相 は電極先端が中央階に入り $\mathrm{E}$ Pが諗められるまでは同 位相であり，中央階では 180 度転換した。負電位と $\mathrm{E}$ Pの閐には不安定な零電位が記録されることがあり， その際にはCM以著明に縮少した（図1，左）。基底膜 の外側端を血管条飞向って刺入すると E P が得られる までと5〜8回負霆位が記録されることがあった。

直流記録で負電位が示される部位ではマーキングを 行うと surface preparation そ执いてラセン器の単一 の細胞が染色されていた。負電位と共飞 CMの增大す る例では一個の毛細胞にマーキングスポットが検出さ れた（図2）。細胞外にマーキングを試みてあスポット は検出できず細胞内刺入時にのみ認められるので，負 軋位はラセン器細胞群の細胞内静止電位であり，した がって毛細胞刺入時の CMは音刺激江対する毛細胞内 の䨞気的な反応である。

細胞内静止電位の大きさは細胞により異り，10m V

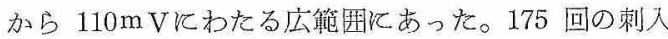
時の負電位の大ささについて分布を調べてみると，2 つのピークが認められ $10 \sim 20 \mathrm{mV}$ と $70 \sim 80 \mathrm{mV}$ の ものが多かった（図3）。ラセン器の細胞内刺入㭙炕み られるCMO大きされついて分布をみると，正円空上 の CMの振幅汶対し，1〜1.5倍のものが最も多かった が，2〜4.5 倍兽大する群もあった（図 4)。細胞内 CMの大きくなる例ではマーキングによって丰細胞に 染色スポットが認められた。刺入陌後の毛細胞内CM の振幅は $0.5 \mathrm{~m} \mathrm{~V}$ 以下であった。しかし，刺入後静上

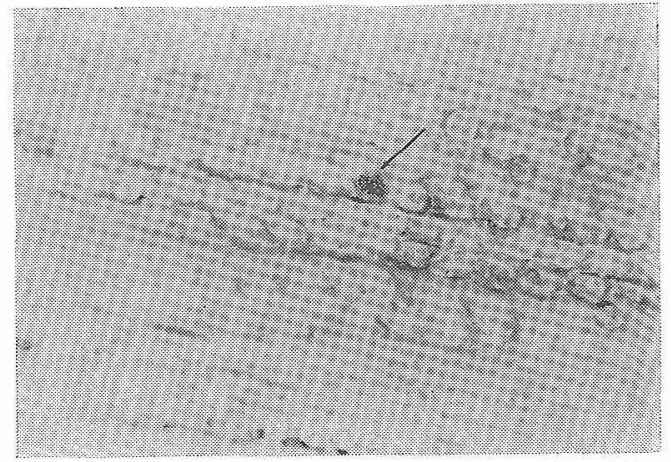

図 2 surface preparation 上飞持ける単一の染 色された細胞。矢印は外毛細胞第 3 列火郝ける

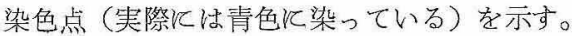


電位が縮少するような時，また電極先端の経が $2 \mu$ あ るいはそれ以上飞太い時飞さらに大きい振幅の CMが 認められた。CMの増大しない群はマーキングでは支 持細胞であった。支持細胞内 CMは静止電位が縮少し ても変化することはなかった。

支持細胞と毛細胞刺入時の電位記録を此較すると次 のようである(図5)。図5亿括いて電極先端が鼓室階を 経て基底膜佉すると，まず小さい負電位が認められ

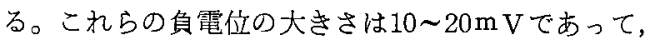
ラセン器の鼓室階側の細胞の静止電位と考元られる。

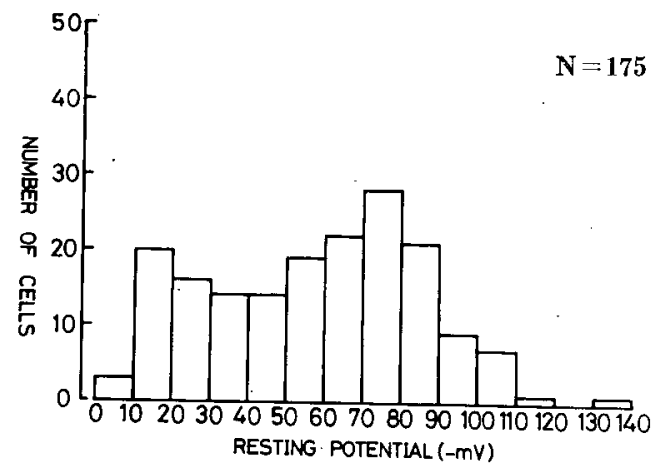

図 3 ラセン器刺入時飞記録された細胞内静止電 位の大きさによる分布。

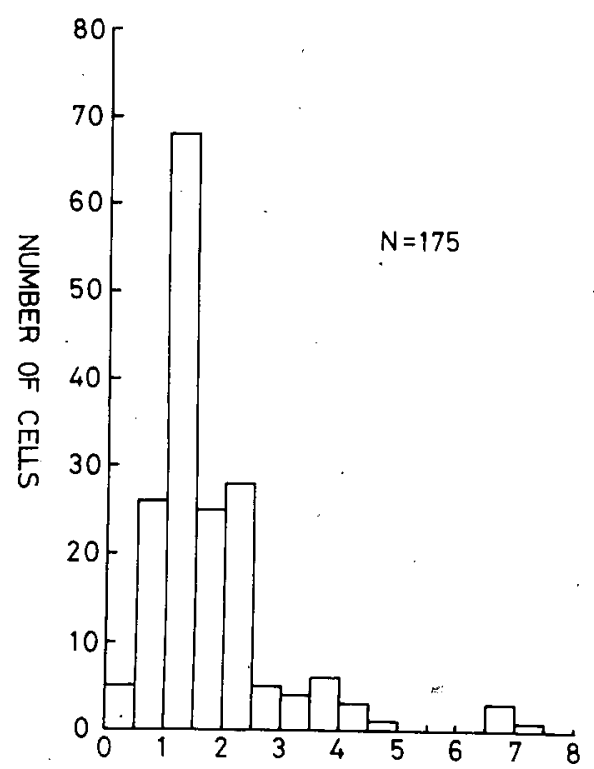

MICROPHONIC RESPONSE (CELL/R.W.)

図 4 ラセン器の細胞内マイクロホン電位の大き さによる分布。細胞内CMの大きさは刺入ごと の正円空上CMの大きさとの比で示されている。
この電位の部位で C Mの大きさは鼓室階のあのと較べ 变らない。さらに電極を進めると $60 \sim 90 \mathrm{~m} \mathrm{~V}$ の大き い負電位が得られる。大きい静止電位を示す細胞群で は CMが増大することがある。細胞マーキングの結果 から，CMが増大する場合は毛細胞を刺入しているの であり，CMが増大しない場合は支持細胞である。

細胞内静止電位と共K CMが增大するような刺入に 和いて, 電極をさらに中央階に向って進めると, “直流 記録では E P が得られる直前に不安定な零電位が記録 され，その部位で CMは著明演少した（図1)。この 部位は形態学的な関係加蓋膜または蓋膜下腔と考え られる。CMの位相㶤つては，この不安定な零電位 が得られた 15 例のうち 14 例がこの電位と E Pの間で 180 度転換し，1例のみが正電位化傾き中央階のもの と同位相であった（表1）。蓋膜部のものと考えられる 電位を同定するためと Co 沈着法を試みたが，電気泳 動的に Co イオンを流出させただけでは沈着物を検出 することが困難であったので，正円空よりクラディウ 一細胞部を経た刺入により塩化コバルト溶液の中央階 灌流を行った。約 $1 \mathrm{~mm}^{3}$ の $200 \mathrm{mM}$ 塩化コバルト溶
DC
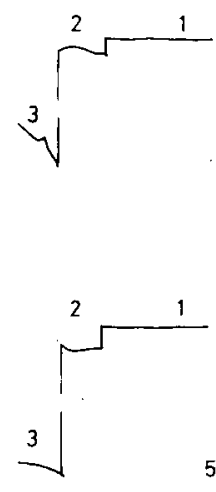

$C M$

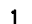

2

図 5 ラセン器刺入時にみられる電位記録の二つ の形。1: 鼓室階, 2: 鼓室階寄りの細胞, 3: ラセン器の細胞, 図上は支持細胞刺入時の記録, 図下注毛細胞の刺入時記録（3のところでCM が増大している)。

表 1 不安定な零電位の部位飞括けるCMの位相。

\begin{tabular}{l|l|c}
\hline phase of CM & d.c. level & No. of cases \\
\hline same to ST & near zero & 14 \\
same to SM & positive & 1 \\
\hline
\end{tabular}




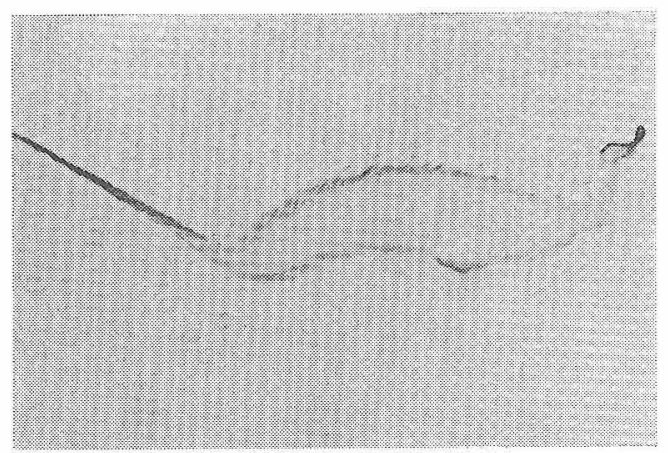

図 6 経正円空刺入により中央階へコバルトイオ ンを注入した際の第 3 回転に和ける盖膜所見。 蓋膜を括括う全表層にコバルト沈着が認められ る。

液注入ルより，CM 15 分で死後 CMの大きさに縮 少し, E Pは半隇した。蝸牛は摘出後, 硫化アンモン 溶液に浸し発色させた。 surface preparation ではラ イスネル膜执よび蓋膜部に沿って黒色のCo 沈着物が 観察され，radial section ではライスネル膜の内リン パ側，蓋膜の表層（図6），ラセン器ならびル内ラセン 絴表面の一部《Co 沈着が検出された。蓋膜ではCo イオンの沈着は外側辺縁部特よび基部㵊も強く，次 いで蓋膜の上下面とす全域にわたって一様な発色が認 められた。

\section{考按}

ラセン器刺入時化記録されるところのいわゆる「コ ルチ器負電位」が intracellular のあのかあるいは inter-cellularのものかという問題に刘し，細胞マーキ ングの成績はこの電位がラセン器の細胞群の細胞内静 止電位であることを示して初り，負電位が細胞由来の

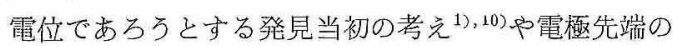
軌跡を組織学的飞検討している推测 ${ }^{7}$ ，9 先実証するも のである。しかしながら，Butler ${ }^{2)}$ が負電位を細胞外 のものであるうと結論した根㧥は先端径が $25 \mu$ の電 極でも記録し得たといらことであるが，比較的太い先 端の電極でも橓時記録できることは事実である。この 点では疑問がいささか残っている。

毛細胞内CMは鼓室階またはラセン器細胞外のもの より大きいけれど毛，振幅の大きさは $0.5 \mathrm{mV}$ 以下で あった。水生動物の側線器汇約いても, 毛細胞内のマ イクロホン電位の大きさは $1 \mathrm{mV}$ 以下と報告されて扔 $り^{4), 5)}$ ，これらの電位は聴側線系飞持ける受容器電位 と一応は考えられるものであるけれども，毛細胞下端
そおいて化学伝達物質の放出を殹動させるためのもの としては十分な大きさではない。毛細胞内 CMは細胞 内静止電位が隇少する時増大する傾向があることま た比較的太い先端の電極で大きく記録できることなど は毛細胞膜の歪み炕関係したことがらかも知れない。

電極の先端がラセン器を貫通して中央階に入る際に 細胞内静止電位と E P の間に不安定な零近辺の電位が 存在することは，以前に Lawrence ${ }^{6)}$ が報告している 通りであって，蓋膜または蓝膜下腔の電位と考えられ る。この部位で直流レベルが極めて不安定なこと，毛 細胞部の貫通時《のみ記録できることから蓋膜部の電 位であることが推測される。蓋膜の上下面を被うすべ ての表層が Co イオンを捕捉し易い性質をもっている ことは高Kイオン濃度の内リンパとの関連に秃いて重 要である。蓋膜下腔の電位は現時点ではいまだ明確に はされていないけれども, 蓋膜の上下面が共にCoイオ ン飞対し同じ性質を有していることや CMの位相の転 換が笥膜と中央階の境介で行われることなどは， $\mathrm{CM}$ の発生が蓋膜を被う表層火関係していることを示唆し ている。前述のようと毛細胞内 CMは变換過程の一段 階と考えるためには不十分な大きさのものであって, 蓋膜表層をむ含めた毛細胞感覚毛側の陽イオン飞対す る特異な性質が受容機序の初期過程飞重要な役割を果 しているものと考元られる。

$$
\text { 本研究の一部はNHK委託研究費によった。 }
$$

\section{Microphonic and DC Potentials in the Organ of Corti and the Tectorial Membrane} by

Yasuo Tanaka*, Atsushi Asanuma, Keiji Yanagisawa, and Yasuji Katsuki** Department of Physiology, School of Dentistry, Tsurumi University

* from Kyoto Prefectural University of Medicine ** from Tokyo Medical and Dental University

Microphonic responses and dc potentials recorded within the organ of Corti in guinea pigs were re-examined by means of the marking technique. Marked spots were detected in single cells on surface preparations of the organ of Corti. The result of cell markings substantiates that the negative potential of the organ of Corti is an intracellular potential. The microphonic potential within hair cells was 2 to 4.5 fold larger than 
that of the extracellular space of the organ of Corti or that of the scala tympani. However, the intracellular microphonics were less than $0.5 \mathrm{mV}$ in size of their amplitude.

As a microelectrode advanced through hair cells, into the scala media unstable near zero potentials were recorded between the intracellular potential and the endocochlear potential. A phase reversal of microphonics took place in the boundary between the unstable zero potential and the endocochlear potential. All surfaces of the tectorial membrane and a partial surface of the organ of Corti had an affinity for cobalt ions which were injected into the scala media. It is deducible that the unstable zero potential is inside the tectorial membrane. The cover surfaces of the tectorial membrane and the organ of Corti may be related to generation of cochlear microphonics.

\section{文献}

1) Békésy, . G. von: DC resting potentials inside the cochlear partition. J. Acoust. Soc. Am., 24; 72-76, 1952.

2) Butler, R. A.: Some experimental observations on the $\mathrm{dc}$ resting potentials in the guinea pig-cochlea. J. Acoust. Soc. Am., 37; 429-433, 1965.

3) Davis, H.: A mechano-electrical theory of cochlear action. Ann. Otol., 67; 789-802, 1958.

4) Flock, A., M. J $\phi$ rgensen, and I. Russell: The physiology of individual hair cells and their synapses. In basic mechanisms in hearing. (ed.) A.R. Mфller, Academic Press, New York and London, 1973.

5) Harris, G. G., L.S. Frishkopf, and A. Flock: Receptor potentials from hair cells of the lateral line. Science, 167; 76-79, 1970.

6) Lawrence, M.: Electric polarization of the tectorial membrane. Ann. Otol., 76; 287-312, 1967.

7) Lawrence, M., A.L. Nuttall, and M.P. Clapper: Electrical potentials and fluid boundaries within the organ of Corti. J. Acoust. Soc. Am., 55; 122-138, 1974

8) Pitman, R.M., C.D. Tweedle, and M.J. Cohen: Branching of central neurons: Intracellular cobalt injection for light and electron microscopy. Science, 176; 412-414, 1972.

9) Sohmer, H.S., W.T. Peak, and T.F. Weiss: Intracochlear potential recorded with micropipets. I. Correlations with micropipet location.

J. Acoust. Soc. Am., 50; 572-586, 1971.

10) Tasaki, I., H. Davis, and D.H. Eldredge: Exploration of cochlear potentials in guinea pig with a microelectrode. J. Acoust. Soc. Am., 26; 765-773, 1954.

11）田中康夫, 井上靖二, 中村文雄: マーキング法に よるコルチ器負電位の細胞同定. Audiology Japan, 11; 319-320, 1968.

（受付 50.4.1) 